\title{
The Role of Husband and Wife in Child Care From Islamic Law Perspectives
}

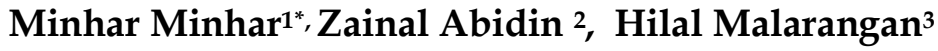 \\ ${ }^{1}$ Islamic Law Department, Postgraduate, Institut Agama Islam Negeri Palu \\ ${ }_{2}^{2}$ Islamic Law Department, Postgraduate, Institut Agama Islam Negeri Palu \\ ${ }^{3}$ Faculty of Islamic Economis and Business, Institut Agama Islam Negeri Palu
}

\begin{abstract}
This paper discusses the role of husband and wife in child care from

Islamic perspective. This study uses qualitative methods and data was gathered through observation, in-depth interviews, and written material. Data analysis was analyzed using grounded theory approach. The results show that parenting activities in the village of Tinggede are not only about rising children, but also about educating, guiding, and protecting children from childhood to adulthood in accordance with Islamic values, norms and culture. The parents expect their children can grow and develop naturally, harmony, and balance based on Islamic teaching. Parenting in Islamic law (hadhanah) is a responsibility of both parents who must get special attention from their parents in particular during childhood period. The authors conclude that parents should accompany their children with Islamic values and norms to inculcate religious behavior of their children.
\end{abstract}

ARTICLE

INFORMATION

Keywords:

Husband, Wife,

Childcare, Islamic law 


\section{Introduction}

Family is the first environment for children. The rational is that the smallest institution (family) in our society has influenced development stage of individual members, including children. It is this group that gives birth to individuals with various forms of personality in society. Therefore it is undeniable that family actually has a function that is not only limited to bring offspring in our society. ${ }^{1}$

When a child was born every parent really wants that child to be a godly child. To enable this to come to existence, educational process where children go through and experience must also be right. The duty of a father and a mother is not only to provide protection, food and clothes, but also being responsible for providing emotional protection and safety from negative influences on their children.

Basic education provided by fathers and mothers and strong religious teachings are very important to avoid unwanted symptoms. Hence, family environment is very influential for children's lives. This is not only for glory, but also more than that, degree of responsibility in a family. ${ }^{2}$

The functions and duties of women are in accordance with nature of their women, among others; woman (wife) is a leader in household affairs. Meanwhile, a husband is a leader in family affairs. In practice, leadership and family tasks are mostly done by

1 Mardiya,Kiat Kiat Khusus Membangun Keluarga Sejahtera (Jakarta: BKKBN, 2002), 10.

2 Ibid., 11 women. With her gentleness, a woman as a housewife can act as a balancing factor for men in family life. The role of a wife can help her husband in taking care of their house and children. ${ }^{3}$

Every mother when she is married must dream of getting pregnant and giving birth to a child, and this is the nature of every woman who is not easy to live, because it should be a struggle for any women. When a woman is pregnant, she endures unspeakable pains taking. It would give her experience between life and death. The household is a small kingdom of a family and therefore indeed it is proper to be led by a man. A man could be a priest in a family. The degree of male leadership is always above women. ${ }^{4}$

Allah has outlined something very special for women. He (God) has bestowed them with emotional and feeling stronger than their rationality. ${ }^{5}$ Therefore, we see a mother who goes through her days beside her son who is lying on bed. They can still survive and feel heavy burden of their husbands and children when they have to go through a crisis. In addition, they are able to overcome how difficult it is to educate and raise their children. ${ }^{6}$

3 Hasbi Indra Dkk, Potret Wanita

Shalehah (Jakarta: Pernamadani, 2004), 5-8.

4 Ibid.,

5 Rusli, R. (2018). Fikih Ekologi dan Kearifan Tradisional: Tinjauan Terhadap Konsep Ihya' al-Mawat dan Hima. Hunafa: Jurnal Studia Islamika, 5(3), 287-298.

6 Syaikh Mutawalli Asya'rawi, Fikih Perempuan (Muslimah) Busana Dan Perhiasan, Penghormatan Atas Perempuan, Sampai Wanita Karier (Jakarta: Amzah, 2003), 144.

e-ISSN: 2715-4580 p-ISSN: 2715-8268 
Unlike a mother, a father plays role as a leader in his family. He plays as a role model for his children. Due to this important role, a father will be called a good role model for his children.

A living is a treasure spent by a husband for his wife and children in the form of food, clothes, shelter and other things. Being a father is a pride of every man and because of this he is a priceless gift to his family.

The division of roles between men and women or husband and wife according to the conventional view, is divided into two areas. Private area, which includes households, kitchen matters is fully left to women. While public zone consists of offices, political spheres, village deliberations, trade, agriculture, and others become men's responsibility. Men are expected to be foundation for a family in making a living. On the other hand, women are considered as male supporters who play an important role in household affairs. Even though this role division has not yet reached peak of equality, it is at least regarded as a form of balance between duties of men and women. ${ }^{7}$

A husband is a priest for his wife, a head of a family, and a head of school for his children. Hence, a competent husband is obliged to provide religious guidance to his wife which allows for his wife's faith to improve. As a husband is a role model for his wife and children he is expected to be ideal

7 Abdul Monir Yacoob dan Siti Shamsiah, Hukum Keluarga Islam (Jakarta: Kencana, 2006), 23. husband where his wife and progenies could learn faith from.

A husband in carrying out his role in his family while he cannot provide adequate living for members of family (his wife and children), a wife could work for supporting her family. However, wives who work could potentially cause problems of disharmony in a family. Many cases where wives have to work today because their husbands could not carry out their duties properly. In this context, wives in their working career could not take care of their household appropriately as they have to work at the same time. As a result, burden on these types wives increases.

In Islam, duties of a husband and a wife do not only revolve around providing protection, food and clothing, but they are also responsible for providing emotional protection and safety from negative influences. Basic education provided by husband and wife, especially good religious teachings, is very important to avoid unwanted symptoms, because family environment plays an important role in inculcating good character for their children.

Household as a formation of a family should be fostered by a wise husband. However, a degree of leadership of a husband over his wife is not only a degree of glory. Rather, it is a degree of responsibility in his family.

\section{Literature Review}

2.1 Parenting Children in Islam

According to Ahmad Tafsir, parenting means education, while e-ISSN: 2715-4580 p-ISSN: 2715-8268 
education is conscious guidance in physical and spiritual development of students towards formation of primary personality. ${ }^{8}$ Gunarso made mention that:

Parenting is a way for parents to act, interact, and guide their children 9 as an activity which involves many specific behaviors individually and collectively. Another view on parenting toward children is a form of interaction between children and caregivers during parenting activities which means caregivers educate, guide and inculcate sense of discipline and protect children to achieve maturity in accordance with norms acceptable in society. ${ }^{10}$

The pattern of care provided by caregivers to foster children can be in physical or psychological form. This is reflected in speech, attitudes, behavior and actions. ${ }^{11}$

The pattern of care is an overall interaction between caregivers with foster children, where caregivers intend to stimulate their children by changing behavior, knowledge and values that are considered most appropriate by caregivers. Thus, children can be independent, grow and develop in a healthy and good manner. All attitudes

${ }^{8}$ Danny I. Yatim Irwanto, Kepribadian Keluarga Narkotika (Jakarta: Arcan, 1991), 94.

9 Yulia Singgih D. Gunarsa, Psikologi Anak dan Remaja (Jakarta: BPK Gunung Mulia, 2002), 37.

${ }^{10}$ Harris Clemes, Mengajarkan Disisplin Kepada Anak (Jakarta: Mitra Utama, 1996), 28.

11 Theo Riyanto, Pembelajaran Sebagai Proses Bimbingan Pribadi (Jakarta: Gramedia, Widiasarana Indonesia, 2002), 89. and behaviors of children while in the orphanage are very much influenced by the pattern of caregiving by their caregiver. This in the long run has a strong influence on children's mental development. Since they could have different backgrounds, it fits for caregivers to choose an ideal parenting for them. In practice, however, many caregivers are still too rigid and limited to one type of parenting. They could not adapt to context and needs as well abilities of children under their control.

\section{a. Types of Parenting}

Types of parenting in general according to Baumrind cited in Kartono consists of four types of parenting patterns:

\section{1) Democratic Parenting}

Democratic parenting is a type of parenting that prioritizes the interests of children, but it does not hesitate to control them. Caregivers with this type are rational and they always base their actions on reasons or thoughts. This type of caregiver is also realistic about children's abilities, not expecting excessively from children under their control beyond their abilities. Caregivers of this type also give freedom to children to choose and be friendly to them.

According to Hurlock, democratic parenting implements twoway communication in implementing rules. They see that children have rights to know why these regulations are made, and they are given opportunities to express their own opinions when they consider the rules being imposed are unfair. Even though children is still e-ISSN: 2715-4580 p-ISSN: 2715-8268 
insignificant in terms of power, they should be given an explanation of the rules being implemented. Since democratic caregivers do not expect foster children to obey their rules blindly, they would never behave harsh to children under their control and thereby physical punishment are rarely given. ${ }^{12}$

The characteristics of democratic parenting are as follows:

a) Determine rules and sense of discipline on the basis of reasonable and acceptable reasons they must be understood by children.

b) Give direction about how to act appropriately and good manners must be maintained by children.

c) Give guidance with understanding.

d) Create harmony as in a family at the Orphanage.

e) Create a communicative atmosphere between caregivers, children and fellow families. ${ }^{13}$

\section{2) Authoritarian parenting}

In Indonesian dictionary, authoritarian means having power alone and arbitrary. ${ }^{14}$ Singgih D. Gunarsaa defines authoritarian parenting is a form of parenting that requires children to be obedient to all orders and rules made by caregivers

12 Elizabeth, B. Hurlock. Perkembangan Anak Jilid II, (Jakarta: Erlangga, 1995), 94.

${ }^{13}$ Zahara Idris dan Lisma Jamal, Pengantar Pendidikan (Jakarta: Gramedia, Widiasarana, 2002), 88.

14 Depdikbud, Kamus Besar Bahasa Indonesia, (Jakarta: Bulan Bintang, 1996), 692. without any freedom to ask or express their own opinions. ${ }^{15}$

Hurlock views that authoritarian parents apply rules and notices to children that must be obeyed. Caregiver does not explain to children why they must be obedient. Children are not given opportunities to express their opinions about fairness of rules being implemented or whether the rules are reasonable or not. If children do not obey rules, they will be given penalties. Authoritarian caregivers assume that punishment is an effective way to prevent rule violations in the future. ${ }^{16}$ This opinion is supported by Barnadib. In his view, authoritarian caregivers are deemed as role holders. All power is in them, and all children's activities are determined by them. Children have absolutely no right to express opinions. ${ }^{17}$

This type of upbringing tends to set absolute standards that must be obeyed, usually accompanied by threats. This type of caregiver tends to force, rule, punish. If children do not want to do what their caregivers say, caregivers do not hesitate to punish children under their control. Caregivers like this also do not know how to compromise in one-way communication. They do not need

15 Singgih D. Gunasa, Psikologi Perkembangan Anak dan Remaja (Jakarta: PT BPK Gunung Mulia, 1995), 87.

${ }^{16}$ Hurlock, Perkembangan, 93.

${ }^{17}$ Sutari Imam Barnadib, Pengantar Ilmu Pendidikan Sistematis (Yogyakarta: offset, 1995), 123. 
feedback from their foster children to understand.

The characteristics of authoritarian parenting are as follows:

a) Children must obey rules of caregiver and must not refute them.

b) Caregivers tend to look for children's mistakes and then punish them.

c) Caregivers tend to give commands and prohibitions to children.

d) If there is a difference in opinion between caregivers and children, it is considered a rebellious.

e) Caregivers tend to impose discipline.

f) Caregivers tend to force things on children and children are only the objects of the rules.

g) Lack of communication between caregivers and children. ${ }^{18}$

\section{3) Permissive Parenting}

Permissive care is type of care that gives full freedom to children to choose and regulate their behavior. ${ }^{19}$ This pattern of nurture is reversed to authoritarian parenting. Said Hurlock made mention that permissive caregivers do not teach rules to their foster children. Children are often not given boundaries or constraints that govern what may and should not be done. They are given permission to make their own decisions. They are not punished for violating, nor are they

18 Zahara Idris dan Lisma Jamal, Pengantar Pendidikan (Jakarta: Gramedia, 1998) 88.

19 Arini Hidayah, Televisi dan Perkembangan Sosial Anak (Yogyakarta: Pustaka pelajar, 1998), 45. rewarded when they behave socially well. ${ }^{20}$

This pattern provides very loose supervision. It provides opportunities for foster children to do something without adequate supervision of their caregivers. They tend not to reprimand or warn if their foster children are in trouble or danger and very little guidance is given to them.

However, this type of caregiver is usually warm which is liked by children. Permissive parenting are elaborated as follows:

a) Let children act alone without monitoring and guiding them.

b) Educating foster children indifferently, being passive and indifferent.

c) Prioritize material needs only.

d) Let alone what children do (giving too much freedom to regulate themselves without any rules and norms outlined by caregivers).

e) Lack of intimacy and warm relationships in family. ${ }^{21}$

M. Thalib states permissive caregivers as follows:

a). Not strict in implementing regulations.

b). Children are given freedom to do and fulfill their desires. ${ }^{22}$

Permissive care patterns are characterized by unlimited freedom to children to behave according to their

90.

${ }^{20}$ Hurlock, Perkembangan Anak, 93.

${ }^{21}$ Idris dan Lisma Jamal, Pengantar, 89-

${ }^{22}$ M. Thalib, 40 Tanggung Jawab Orang Tua Terhadap Anak, (Bandung: Irsyad Baitus Salam, 1995), 7-9.

e-ISSN: $2715-4580$ p-ISSN: 2715-8268 
own desires. ${ }^{23}$ Caregivers do not provide rules or direct foster children to the right path. The child does not understand whether his behavior is right or wrong because his caregiver never justifies or blames his foster child.

Consequently, foster child will behave according to his own desires, no matter whether it is in accordance with community norms or not. ${ }^{24}$

\section{4) Abused Parenting}

These types of caregivers generally give very little time and money to their foster children. A lot of time is used for their personal needs, such as working to provide minimal costs for children's needs. ${ }^{25}$

This parenting style has characteristics stated by Gunarsah:

1) Caregivers spend more time outside their house

2) Attention given to children development is lacking

3) Allowing foster children to get along too freely outside their house. ${ }^{26}$

Children are one of the gifts given by God to someone. Without children there will be no sign of life in a family.

b. Factors that influence parenting

${ }^{23}$ Rusli, R. (2009). Gagasan Khaled Abu Fadl tentang "Islam Moderat" versus "Islam Puritan" (Perspektif Sosiologi Pengetahuan). Jurnal Ilmiah Ilmu Ushuluddin, 8(1), 99-123

24 Danny I. Yatim, Kepribadian Keluarga Narkotika (Jakarta: Arcan, 1991), 97.

${ }^{25}$ Kartini Kartini, Peran Orang Tua Dalam Memandu Anak, (Jakarta: Rajawali, 1992), 39.

26 Gunarsa, Psikologi, 56.
There are several factors that affect parenting / caregivers for foster children, including:

1) Gender

Caregivers tend to be harder on girls than boys.

2) Culture

Background of children creates differences in childcare patterns. This is also related to different roles between men and women in a society's culture.

\section{c. Social status}

Caregivers with low educational background, middle and lower class economic levels tend to be tougher, coercive and less tolerant than those from upper class family. However, they are more consistent. ${ }^{27}$

\subsection{Husband and Wife Leadership in the House}

A leader is someone who has the ability to influence and move others to achieve goals. Success or failure of an organization depends on the ability of leadership in moving all members of the organization to achieve their goals. Courtois in Sutarto describes that "groups without leaders such as bodies without heads, easily become heretics, panic, chaos, anarchy and others". 28

Leaders must have a desire to lead. Various studies confirm that a strong desire to lead many people is characteristics of effective leaders. Furthermore, Bass Edwin explained that leaders are more resilient in dealing with obstacles than non-leaders and

\footnotetext{
27 Ibid.,

28 Sutarto, Kepemimpinan (Jakarta: Gema Press, 2008), 46.
}

e-ISSN: 2715-4580 p-ISSN: 2715-8268 
have capacity to work with goals that are far ahead and have a level of will power or determination. Leaders prefer actions that challenge a process rather than simply wait while giving a smile. Effective leaders usually use a catch approach and endlessly show greater initiative compared to non-leaders. ${ }^{29}$

If viewed in the Islamic concept, the task of humans as leaders on earth is to prosper nature as a manifestation of human gratitude to God Almighty and a form of devotion to Him. The task of $k h a l i \bar{f} a h$ is given to every human being. In the implementation, it contains attitude of togetherness or mutual accountability to Allah and this would lead to prosperity of the nature. This concept gave birth to very important values about the "Leader" and members or those led, and situation in which leadership takes place.

For every people there is a leader who is trusted so that they can teach truth, goodness, and glory through his example. The leader must be a helper, motivator, director and guiding member of an organization to obey the will of Allah Almighty. God's Word swt. in Q.S. At-Taubah [9]: 71 which translates as follows:

And those who believe, men and women, some of them are helpers for some others. They order (do) good and prevent from evil, establish prayers, perform alms, and they obey Allah and His Messenger. They will be given

29 Edwin, Kepemimpinan Transformatif (Bandung: Risalah, 2007), 12 mercy by God; Surely Allah is Mighty, Wise. ${ }^{30}$

\section{Methodology}

This study uses qualitative approach investigating Muslim families in Tinggede, a village located in Marawola Sub-district, Sigi. The informants of this study are the head of the village, Religious Leaders, Community Leaders, Traditional Leaders and Communities in Tinggede at large.

Data were collected through observations, in-depth interviews and shared written documents. Data analysis consists of several procedures: reduction and verification techniques with various data sources. ${ }^{31}$ 32The reduced data is then analyzed reflecting on theoretical concepts used in this study. ${ }^{33}$

\section{Result and Discussion}

4.1 Role of Husband and Wife in Child Care

${ }^{30}$ Departemen Agama RI, Al-Qur'an,198.

31 Nurdin, N. (2017a). Research in Online Space: The Use of Social Media for Research Setting Jurnal Sistem Informasi (Journal of Information System), 13(1), 67-77.

32 Nurdin, N. (2017b). To Research Online or Not to Research Online: Using Internet-Based Research in Islamic Studies Context. Indonesian Journal of Islam and Muslim Societies, 7(1), 31-54.

33 Nurdin, N. (2016). The Roles of Information Technology in Islamic Bank Knowledge Management: A study of Two Syariah Banks in Palu. Hunafa: Jurnal Studia Islamika, 13(2), 181-217. https://doi.org/https://doi.org/10.24239/jsi.v 13i2.444.181-217

e-ISSN: $2715-4580$ p-ISSN: 2715-8268 
Family remains the first group (primary group) where foundation of personality is laid and transferred. Parents play role in establishing a system of intimate and long-lasting interactions that are characterized by personal loyalty, love and loving relationships. The role of parents is to help child's mentality develop appropriately. The formation of a child's personality and activities is a capital for adaptation of the child and his environment and brings measured impacts on the overall family welfare.

Nuclear family, the smallest social group of society formed by marriage consists of a husband (father), a wife (mother) and their children. Both parents must love and care their children. When children were brought up with adequate love and affection from their parents, they could easily adapt to situation outside their house and allow them face new problems the way they were brought up. Conversely, if both parents interfere too much in their children's affairs and force their children to obey them, this would be obstacles for the perfection of their personality.

Abd. Jaar as the Head of the village of Tinggiede revealed that:

Marriage is a type of relationship between men and women who hold a legitimate/lawful bond in marriage according to Islam. It provides rights and obligations, physical and spiritual support, a husband must be responsible for all problems and be a good priest, and the wife's obligation is to serve her husband at the best potential endowed to her and she must not be hurt, meeting physical and spiritual needs. The way to solve problems is to give mutual understanding, deliberation, avoiding problems, asking for advice from parents. ${ }^{34}$

Father and mother are the first role models for their children in their personality development. To be a good role model, father and mother must practice it for themselves in the first place. The role of parents or the environment towards children's independence must be inculcated at the early age of children. This is considering that independence in children cannot happen by itself. Children need support such as a positive attitude from parents and skills must be delivered through training towards their independence.

In addition, to become an independent person, a child also needs to have the opportunity to practice consistently, for example, doing something on his own or spend it doing tasks that are appropriate to the stage of his age. Parents or the environment do not need to be anxious, overly protective, too helpful or even always take over tasks that children should be doing, because this can hamper the process of achieving child's independence. Opportunities for independent learning can be given by parents or the environment through

\footnotetext{
${ }^{34}$ Abd Jabar, Kepala Desa Tinggede, "Wawancara", Tanggal 9 September 2019.
} 
well-provided freedom and trust to children to carry out their tasks.

However, the role of parents or the environment in supervising, guiding, directing and setting an example is still very necessary. Hence, children remain in conditions or situations that do not endanger their safety. For young children, this independence exercise can be done by involving children in daily practical activities at home, such as training children to take their own drinking water, training children to clean their own bedrooms, training children to go to toilets themselves, training children to provide their own food, training children to go up and down stairs on their own.

Tinggede is one of the villages in Marawola Sub-district, Sigi Regency, which consists of various tribes and religions, most of whom are of Kaili ethnicity and Muslim. Based on the questions addressed this thesis, the community's understanding about their ways of educating and caring for children is described in the following ways:

\subsection{Role of Husband and Wife / Parents against Children}

The role of husband and wife subsequently is indeed very important in shaping personality of children because social interactions in children's social life begins with the ways their respective parents up-bring them. Based on the pattern of parents' education that they apply, a child can record what they receive from their parents.
Hence, the pattern of education that parents give them will be applied in their lives to come. For example, religious pattern of students, which is reflected on the way of students' parents up-bring their children would be brought up in the future community life of the children. Religious education is felt to be very important especially in a critical life like today.

Every parent really wants his children to live well in society, many ways taken by parents in inculcating religious attitudes early on in their children, one of which is expressed by Mr. Abdul Jabar in this way:

In the care of children the most important thing is the formation of religious behavior, for me especially for my child, from an early age I always teach my children good religious behavior with the aim that later my child can understand and can distinguish which actions may be done and which are prohibited and not fall into negative things. "35

Every parent really wants their children to become good children in their lives, so that they become children that are in line with their parents' expectations. The same thing was expressed by Ms. Nikma:

I do not always indoctrinate my child to be what I want, but I always instill self-awareness of my child, sir ... so that without watching him, I believe my child can distinguish between what is

35 Abd. Jabar, Kepala Desa Tinggede, "Wawancara", Tanggal 9 September 2019.

e-ISSN: $2715-4580$ p-ISSN: 2715-8268 
good and bad, I began to inculcate that awareness since they were still young so that there will be fear of doing things that are forbidden by religion" 36

Mr. Arsyad, a farmer also said something similar to inculcation of religious education patterns from early age:

Religious attitude is indeed very important, sir, in people's lives, especially as we who live together side by side like this, we always need other people, I always teach my children so that my children can become teachers (role models) in their future lives. ${ }^{37}$

Based on the interviews, although the village of Tinggede is sometimes labeled as one of the villages prone to fights between youths, most parents recognize that religious education is the most important thing in childcare. There are other reasons expressed by parents to instill religious education early on, one of which is expressed by Mrs. Fajrah as follows:

In my opinion, sir ... in the care of children the most important thing is inculcating religious values. Religious-based attitudes that I taught my children from early age is aimed at making my child behave well in the community, whether they are at home, school

36 Nikma, Orang Tua, (Warga Desa Tinggede) "Wawancara", Tanggal 12 September 2019.

37 Arsyad, Orang tua (Warga Desa Tinggede) "Wawancara", Tanggal 13 September 2019. or neighborhood, and certainly so that my child could live independently with a strong religious foundation, so I would not worry that my child will be far from supervision of those closest to him. ${ }^{38}$

There are various reasons arising from the ways of parents thinking which appear in religious values embraced by their children. Amongst them are methods used by Ms. Ervina who works as a housewife, she revealed her experience in the following way:

In looking after my children, in addition to my obligation to send my children to school, sir ... one of my ways in fostering religious behavior in my children, I usually advise him to follow religious organizations, so that my child will understand for himself the importance of applying religious values in society. ${ }^{39}$

Parenting practised in the village of Tinggede in addition to sending their children to school is based on religious values. The ways of parents fostering religious behavior vary greatly because differences in terms of education. One of them was revealed by Mr. Aswadin:

For me, sir, besides sending my children to provide a good living for their wives, of course. I always teach my children good manners wherever they are, respect for

38 Fajrah, Orang Tua (Warga Desa Tinggede), Tanggal 16 September 2019.

39 Ervina, Tokoh Pendidik, Orang tua (Warga Desa Tinggede), Tanggal 19 September 2019.

e-ISSN: 2715-4580

p-ISSN: 2715-8268 
others, so that if my children wherever they will always respect others and be respected by others. ${ }^{40}$

Besides, another method was also revealed by Mr. Basir whose education was only up to elementary school, he revealed his experience in the following way:

My wife and I work as a sand digger and my wife as a washing laborer, in educating children is difficult sir, I only graduate primary school sir, because sometimes I forget that children also need attention and advice, but slowly slowly I will educate my children so that they do not follow my footsteps and can get a better job than mine even though I only work as a sand digger and my wife as a washing laborer, I do not forget to send my children to higher education. ${ }^{41}$

The methods of upbringing children experienced by parents are indeed very diverse. One of the responses expressed by Wahyu as a child, he revealed his experiences being brought up in the following way:

Yes, if my parents teach me about good behavior, I always respond positively, because I think that the old man's advice is not likely to make my life difficult sir, so I am very happy if I was given advice

40 Aswadin, Orang tua (Warga Desa Tinggede), "Wawancara", Tanggal 20 September 2019.

41 Basir, Orang tua (Warga Desa Tinggede) "Wawancara", Tanggal 23 September 2019. by my parents, in any case their advice is unlikely to harm us. ${ }^{42}$

The results of interviews showed that there are many ways that parents take to educate their children to become useful generations in the future. Various ways taken by parents so that their children do not fall into undesirable behavior in their social life ahead. Despite the case, there are some parents who seem to be ignorant when it comes to educating their children. There are those who educate their children very hard and this has something to do with their education. In their view, being hard to children would allow them to become more obedient. However, this is the case where children become more disobedient, as evidenced by the above interview. With a strict parenting, children will be more defiant and ignorant of their parents' advice.

The various reasons revealed above can in fact be concluded that the level of education of parents strongly influences the ways of children behaving in their community. Knowledge obtained by parents in shaping children's personality is limited due to poor parents' education.

Reflecting on the experiences of the villagers, family has a great role in shaping children's personality because family has a function as the first socialization setting for children. In a family the major role is performed by parents.

42 Wahyu, Remaja, (Warga Desa Tinggede) "Wawancara", Tanggal 23 September 2019.

e-ISSN: 2715-4580

p-ISSN: 2715-8268 
The role played by parents is quite large in addition to fulfilling daily needs of their children. Parents are also required to educate children so that their children would grow in accordance with their expectations. This heavy role was also felt by Mr. Saiful where he educated 2 children, he revealed his experiences in the following way:

Children are entrusted by God, sir, so we must guard, educate, and raise them to become useful children later, the most difficult thing for me to experience when my child has plunged into the community, I am afraid that my child will fall into bad things. ${ }^{43}$

Every parent implements a lot of strategies to educate their children. Their expectation is to help their children avoid negative things in society. One of them expressed by Mrs. Usriah, she revealed her experiences in the following way:

So that my child does not fall into harmful things, as much as possible I send him in a religious school, because I do not want my child to be like his parents, I want my child to be a child who is devoted to his parents and can raise the level of his parents in the view of society. ${ }^{4}$

The same thing conveyed by Ms. Restu, in in educating her children, she

\footnotetext{
${ }^{43}$ Saiful, Orang tua (Warga Desa Tinggede) “Wawancara”, Tanggal 27 September 2019.

44 Usriah, Orang tua (Warga Desa Tinggede) "Wawancara", Tanggal 30 September 2019.
}

revealed her experiences in the following way:

In educating children it is indeed very difficult, sir, especially if the child is easily affected, but I try patiently and patiently in educating children, I always advise him if the correction is wrong, because I am embarrassed sir if my child can be reproached in the community here, eating I always advise him, even though I sometimes argue with my child, but not what is important is that my child should not fall into negative things. ${ }^{45}$

The role played by parents is indeed quite heavy, to educate their children to grow in accordance with their expectations. Many strategies applied by parents in determining what their children's future would be like, it cannot be separated from the role of parents.

On the other hand, children accepted the role played by their parents. The child would immediately give a positive response to parents when their parents give them advice.

Many strategies applied by parents there are authoritarian and some are mediocre. Parents mostly involve their children in religious activities and social activities, it is hoped that their children will be able to live well in community.

However, many obstacles experienced by parents when educating

45 Restu, Orang tua (Warga Desa Tinggede) "Wawancara", Tanggal 30 September 2019.

e-ISSN: 2715-4580 p-ISSN: 2715-8268 
their children. One of their obstacles is when their advice is not listened by their children. Despite the case, parents accept it sincerely and continue to carry out their role as parents. There are cases where parents educate their children through other institutions without reducing their role as parents at home.

There are also cases where parents advise their children to take part in religious activities outside, for example at the Qur'anic Learning Centre (TPA), qur'an recitation, and Sunday school. Besides, many parents also teach children to socialize with each other about environment where they live. This is expected to foster a sense of caring for the surrounding environment including what parents do is to invite their children to do mutual cooperation in their surroundings, follow the activities community in the environment like youth clubs.

One of the values that can be taken by children concerning religiosity instilled by their parents is as expressed by Rudi whose parents are only as a sand miner, he revealed his experience in the following way:

My parents often instill an attitude of mutual respect Sir ... that's what I think is one of the characteristics of religiosity that I have, so that I feel more able to interpret in living this life, more concerned about others, towards surrounding and I obey, I can remember God wherever I am. ${ }^{46}$

46 Rudi, Remaja (Warga Desa Tinggede) "Wawancara", Tanggal 7 Oktober 2019.
In addition, there are other reasons obtained by a child regarding religious values obtained from their upbringing, one of which is expressed by Rita as follows:

From the meaning of religious values inculcated in me from my parents, there are indeed so many sirs. Among them, I can obtain social values that encourage me to carry out social and meaningful activities in the community such as community service here, as well as humanitarian values that I can is that I always help neighbors who need help for example when there is a neighbor who dies, and I get moral values that I behave according to norms and customs set in the village of Tinggede, sir. ${ }^{47}$ Many values obtained from childhood about this religiosity was shown in reasons they revealed. It can be seen in the pattern of parental education explained by the interviewees. Hence, children can understand the pattern of behavior they must apply in community later. From good conduct by children in the environment they live in, many children feel the benefits of religious behavior and this helps them inculcating religious values in their community. One of them was revealed by Syiva:

If I often inculcate kindness, surely I will be treated well wherever I am, sir ... I often help my neighbors if they need help, so the response I get from my neighbor is

\footnotetext{
47 Rita, Remaja (Warga Desa Tinggede) "Wawancara", Tanggal 10 Oktober 2019. e-ISSN: $2715-4580$ p-ISSN: 2715-8268
} 
quite good ... I feel that the people living in my neighborhood are already considered to be my brothers myself, and I will not break the ties of friendship that I have implanted in myself. ${ }^{48}$

In addition, there are other reasons revealed by Nia, she also feels true benefits of implementing good religious attitude in her environment as taught by her parents, she revealed her experience in the following way:

I became more aware of how to live in a society and religion, sir ... so that I became more active in participating in activities carried out in this environment and I became (so close to the people here). Even though I am a migrant in this village. ${ }^{49}$

In addition to the values and benefits derived from religious attitude of children in the community, they really feel what it means to life. Thus, children can bring themselves in their own lives and they can sort out which actions are good and bad.

In social life, of course, we live side by side with other residents, so the attitude we make in this community will certainly get a response from others. This was also felt by the children in implementing religious behavior in the community. Good behavior is always shown by these children so that responses they get in return are also good. One of them revealed by Fajar, he

\footnotetext{
48 Syiva, Remaja (Warga Desa Tinggede)

"Wawancara", Tanggal 10 Oktober 2019.

49 Nia, Remaja (Warga Desa Tinggede)

"Wawancara", Tanggal 10 Oktober 2019.
}

revealed his experience in the following way:

I am here as a youth leader as well as a member of youth here so if there are friends who have interests I always help, if someone dies too so sir.... so that people here also think I am a part of them so I feel being valuable and respected. ${ }^{50}$

Every response that was expressed by the informants was almost all the same, because in their own social life, loyalty was needed in social interactions. Hence, the community can accept it well. This shows that the role of parents is very important in shaping character and children character which they would apply in their environment later. If children do not behave well in their community, the community will automatically look at children's parents. In this view, parents are considered as a reflection of their children.

\section{Conclusions}

The formation of personality is very meaningful. In this context, parents are the first personal coaches in children's life. Parenting activities in the village of Tinggede do not only show how parents treat children, but also indicate how parents educate, guide and protect children from childhood to adulthood according to values, norms and culture embraced in the community. Islamic way of nurturing is one of the ways that parents adopted when it comes to educating children in

\footnotetext{
${ }^{50}$ Fajar, Tokoh Pemuda, (Warga Desa Tinggede) "Wawancara", Tanggal 14 Oktober 2019. e-ISSN: $2715-4580$ p-ISSN: 2715-8268
} 
the village of Tinggede. In the view of Islam, the effort is considered as a real effort from parents in giving thanks to the gift of Allah in performing their mandate. This are the efforts to save children's nature including potential thought, taste, initiative, work as well as children's health.

All these potentials have been carried out by parents in the village of Tinggede appropriately. The aim is to expect children to grow and develop naturally, in harmony and balance, which in turn they would become a source of happiness, successor to their parents. Moreover, they are expected to become independent human beings, shaping children's personality into a whole person who gain intact blessings from the Almighty Allah. Moreover, this is an effort to save children as the next generation as expected by parents.

The efforts made by parents showed that how they played their role as parents in their lives to the best of their potential. Many children in Tinggede Village feel that the role of their parents has a very big impact on their lives. This is what triggers children to guard their actions in accordance with religious principles because they want to make their parents proud.

Parenting children in Islamic law (hadhanah) is responsibility of both parents which must be given special attention. It is a duty of parents to take care of, care for, educate and raise their children based on the teaching of Islam. Parents should closely supervise their children before and when they achieve the ages of puberty, 7-18 years (adolescents) in order to avoid unlawful things or break Shari'ah. To sum up, in carrying out duties of parenting (hadhanah), every parent must always be guided by Islamic rules derived from Qur'an and Al-Hadith.

\section{REFERENCES}

Al-Qur'an dan Terjemahnya

Abdullah, Adil Fathih. Wasiat Rasullah Kepada Kaum Wanita. Solo: AlQowam, 2005.

Abdullah. Faktor-Faktor Yang

Mempengaruhi

Perempuan Bekerja Strategi

Kesejahteran

Sinar Grafika, 1995.

Abdurahman. karakteristik lelaki shālih. Bandung: Gema Press, 2011.

Achdiat. Komunikasi Keluarga. Jakarta: Elka, 2014.

Ahmad Jadi Amuli, Muhammad. Kumpulan Kisah Dalam Al-Quran. Jakarta: Qorina, 2008.

Ahmadi, Abu. Ilmu Sosial Dasar. Jakarta: PT Rineka Cipta, 1991.

Ainurrohmah. http://walisongo. blogspot. com/2016/11/ definisi -sumber -data- danteknik_27. html, Diakses 20 Maret 2019.

Al-Albani, Muhammad Nashiruddin. Ringkasan Shahih Bukhari Jilid 4. Jakarta: Pustaka Azzam, 2007. Al-Qurthubi, Muhammad. Al-Jami' li Ahkam Al-Quran Juz XVIII. Beirut: Dar-al- Ihya li Tirkah al-Arabi, 1985. 
Amin, Munir. Peranan Keluarga Dalam Rumah Tangga. Jakarta: Amzah, 2010.

Amini, Ibrahim. Fatmah Az-Zahra: Wanita Teladan Sepanjang Masa. Jakarta: Lentera, 2006.

Anak di sertai Teladan Kehidupan Para Salaf. Solo: Pustaka Arafah, 2003.

Arifuddin. Keluarga dalam pembentukan Akhlak Islamiah. Yogyakarta: Ombak, 2009.

ASya'rawi, Syaikh Mutawalli. Fikih Perempuan (Muslimah) Busana Dan Perhiasan, Penghormatan Atas Perempuan, Sampai Wanita Karier. Jakarta: AMZAH, 2003.

Azizatun, Ayu dewi. http:// blogspot.com/2015/05/teknikkeabsahan-data.html, Diakses 20 Maret 2019.

Bahreisy, Salim dan Said Bahreisy. Terjemahan Simngkat Ibnu Katsier. Surabaya: PT Bina Ilmu, 1990.

Barnadib, Sutari Imam. Pengantar Ilmu Pendidikan Sistematis. Yogyakarta: offset, 1995.

Clemes, Harris. Mengajarkan Disisplin Kepada Anak. Jakarta: Mitra Utama, 1996.

D Gunarsa, Yulia Singgih. Psikologi Anak dan Remaja. Jakarta : BPK Gunung Mulia, 2002.

Daradjat, Zakiah. Pendidikan Islam Dalam Keluarga dan Sekolah Cet. II. Jakarta: CV. Ruhama, 1995.

Dedi, Supriyadi. Bunga Rampai Sosiologi Keluarga. Bandung: Pustaka Setia, 2008.

Departemen Pendidikan dan Kebudayaan RI. Kamus Besar
Bahasa Indonesia Edisi

II.

Jakarta: Balai Pustaka, 1996

Donelson, Elaine. Asih, Asah, Asuh, dan Keutamaan Wanita. Yogyakarta: Kanisius, 1990.

Durbin. Aplikasi Kepemimpinan Dalam Institusi. Bandung: Yaya Press, 2005.

Dyah, Ratna Meta, dalam, http://metakerenz.blogspot.co.id/201 9/03/ peranan ibu dalam keluarga, Diakses 20 Maret 2019.

Edwin. Kepemimpinan Transformatif. Bandung, Risalah, 2007.

Elmawati. Managerial skills. Jakarta: Prenada Media, 2007.

Faldian,

Nata.

http://.blogspot.com/2014/05/

makalah-penelitian-

kualitatif.html, Diakses 20 Maret 2019

Ghazali, Syeikh Muhammad. Tafsir Tematik Dalam Al-Qur'an, Cet I. Jakarta: Gaya Media Peratama, 2004.

Ghazali, Syeikh Muhammad. Tafsir Tematik: Dalam Al-Qur'an. Jakarta: Gaya Media, 2008.

Hadi Sutrisno. Metodologi Penelitian. Yogyakarta: Andi Ooffset, 1989.

Hakim, Atilal. Manajemen keluarga Islami. Bandung: Citapustaka media perintis, 2009.

Hakim, Rahmat. Hukum Pernikahan Islam. Bandung: Pustaka Setia, 2000.

Hasan, M. Ali. Pedoman Berumah Tangga dalam Islam. Jakarta: Siraja, 2006.

Hawari, Dadang. Ilmu Kedokteran Jiwa dan Kesehatan Jiwa. Yogyakarta: Dana Bakti Prima Yasa, 2004. 
Helmawati. Pendidikan Keluarga. Jakarta: Prenada Media, 2010.

Hendi dan Suhendi, Rahmadani Wahyu. Pengantar Studi Sosiolog Keluarga. Bandung: CV Pustaka Setia, 2000.

Hendri, Novi. Psikologi dan konseling keluarga. Medan: Citapustaka media perintis, 2012.

Hidayah, Arini. Televisi dan Perkembangan Sosial Anak. Yogyakarta: Pustaka pelajar, 1998.

Hurlock, Elizabeth, B. Perkembangan Anak Jilid II. Jakarta: Erlangga, 1995.

Ihsan, Fuad. Dasar-dasar Kependidikan. Jakarta: PT. Rineka Cipta, 2008.

Indra, Hasbi dkk. Potret Wanita Shalehah. Jakarta: Pernamadani, 2004.

Ismail.http://ismail6033.blogspot.com/ 2017/10/makalah-kerangkaberpikir.html, Diakses 20 Maret 2019.

Kahmad, Dadang. Metode Penelitian Agama. Bandung: CV. Pustaka Setia, 2011.

Kartika, Widi Restu. Asas Metodologi Penelitian. Yogyakarta: Graha Ilmu, 2010.

Kartini, Kartono Pengantar Metodologi Riset Sosial. Bandung: Mandar Maju, 1990.

Katsir, Ibnu. Tafsir Ibnu Katsir (Jilid 7) Cetakan Ke. II. Jakarta: Pustaka Imam As-Syafi'I, 2010.

Khoiriyah. Reorentasi Peranan Keluarga dalam Islam. Yogyakarta: Teras, 2012.

Lahij, Rod. Dalam Buaian Nab Merajut Kebahagiaan Si Kecil: Cara Rasullah
SAW Mendidik Dan Menyukseskan Anak. Jakarta: Zahra, 2005.

Lubis, Namora Lumongga. Memahami Dasar-Dasar Konseling. Jakarta: Prenada Media Group, 2011.

M. luddin, Abu bakar. Dasar-Dasar Konseling. Bandung: Citapustaka media Perintis, 2009.

M. Zein, Satria Effendi. Problematika Hukum Keluarga Islam Kontemporer, Analisis Dalam Keluarga. Banda Aceh: Ar-Raniry Press, 2007.

Majid Hasyim, Husaini A. Syarah: Riyadus Shalihin. Diterjemahkan Oleh: Mu'ammal Hamidi dan Imron A. Manan. Surabaya: PT. Bina Ilmu, 1993.

Mansur. Pendidikan Anak Usia Dini dalam Islam. Yogyakarta: Pustaka Pelajar, 2005.

Mardiya. Kiat Kiat Khusus Membangun Keluarga Sejahtera. Jakarta: BKKBN， 2002.

Mashudi, Farid. Psikologi Konseling. Jakarta: IRCiSoD, 2011.

Mohsen Qaraati, Seri Dan. Tafsir Untuk Anak Muda. Jakarta: Al-Huda, 2005.

Muflichana.http://.blogspot.com/2015 /05/makalah-teknik-analisisdata.html, Diakses 20 Maret 2019.

Muhidin, Sambas Ali. Panduan Praktis Memahami Penelitian. Bandung: Pustaka Setia, 2009.

Munawir, Ahmad Warson. Kamus Al Munawwir. Yogyakarta: Gema Press, 1984. 
International Journal of Contemporary Islamic Law and Society

Vol. 2 No. 1 Tahun 2020

Musyahidah, Sitti. Hasil Penelitian Klaster pengembangan Prodi di IAIN Palu: Peran Perempuan dan Remaja MUI dalam Ketahanan Keluarga Perspektif Hukum Islam Propinsi Sulawesi Tengah Palu: LP2M IAIN PALU, 2019.

Myron, Weiner. Modernisasi Dinamika Pertumbuhan. Yogyakarta: Gadjah Mada University Press, 2008.

Mz, Labib. Indahnya Rumah Tangga Sakinah. Surabaya: Putra Jaya, 2007.

Ningsih, Yuni Setia. Birrul Awlad Vs Birrul Walidain Upaya Pendidikan Emosi Anak. Jakarta: Pratama, 2004.

Nurdin, N. (2016). The Roles of Information Technology in Islamic Bank Knowledge Management: A study of Two Syariah Banks in Palu. Hunafa: Jurnal Studia Islamika, 13(2), 181217.

https://doi.org/https://doi.org/ 10.24239/jsi.v13i2.444.181-217

Nurdin, N. (2017a). Research in Online Space: The Use of Social Media for Research Setting Jurnal Sistem Informasi (Journal of Information System), 13(1), 67-77.

Nurdin, N. (2017b). To Research Online or Not to Research Online: Using Internet-Based Research in Islamic Studies Context. Indonesian Journal of Islam and Muslim Societies, 7(1), 31-54.

Rakhmat, Jalaluddin. Keluarga Muslim Dalam Masyarakat Modern. Bandung: PT. Remaja Rosdakarya, 1994.
Ridwan. Skala Pengukuran Variabelvariabel Penelitian. Bandung: Alfabeta, 2011.

Rohmaniyah, Nafi'atur. "metodologi penelitian pendidikan" http://nafimubarok dawam.blogspot.com/2013/05/ metodologipenelitianpendidikan. html?m=1, Diakses 20 Maret 2019.

Rusli, R. (2009). Gagasan Khaled Abu Fadl tentang "Islam Moderat" versus "Islam Puritan" (Perspektif Sosiologi Pengetahuan). Jurnal Ilmiah Ilmu Ushuluddin, 8(1), 99123.

Rusli, R. (2018). Fikih Ekologi dan Kearifan Tradisional: Tinjauan Terhadap Konsep Ihya' al-Mawat dan Hima. Hunafa: Jurnal Studia Islamika, 5(3), 287-298.

Rusyd, Ibnu. Bidayah al-Mujtahid, Penerjemah; M.A. Abdurrahman. Semarang: Asy-Syifa', 1990.

Salam, Lubis. Menuju Keluarga Sakinah Mawaddah dan Warahmah. Surabaya: Terbit Terang, 2007.

Shalih Baharitis, Adnan Hasan. Tangung Jawab Seorang Ayah Terhadap Anak Laki- Laki. Jakarta: Gema Insani,1996.

Shihab, M. Quraish. Tafsir Al-Mishbah: Pesan, Kesan Dan Keserasian AlQur'an. Jakarta: Lentera Hati, 2002.

Siswoyo, Rudi. http:// 89.blogspot.com/2013/11/makal ah-sumber-datapenelitian.html, Diakses 20 Maret 2019. 
Subhan, Zaituna. Membina Keluarga Sakinah. Yogyakarta: Pustaka Pesantren, 2004.

Suharna, Nana. Probelamatika dalam Keluarga. Bandung: PT. AlMa'arif, 1986.

Suharyanto. Pemimpin Masa Depan. Semarang, Alkaff, 2002.

Sukandarrumidi. Metodologi Penelitian. Yogyakarta: Gajah Mada University Press, 2004.

Sutarto. Kepemimpinan. Jakarta: Gema Press, 2008.

Thalib, M. 40 Tanggung Jawab Orang Tua Terhadap Anak. Bandung: Irsyad Baitus Salam, 1995.

Theo, Riyanto. Pembelajaran Sebagai Proses Bimbingan Pribadi. Jakarta: Gramedia, Widiasarana Indonesia, 2002.

Thoha Chabib. Kapita Seleksi Pendidikan Islam. Yogyakarta: Pustaka Pelajar Offset, 1996.

TIM Penyusun Kamus Pusat Pembinaan dan Pengembangan Bahasa. Kamus Besar Bahasa Indonesia. Jakarta, Balai Pustaka, 1988.

Undang-Undang Nomor 35 Tahun 2014 tentang Perlindungan Anak, Pasal 1

Undang-undang perkawinan Nomor 1 Tahun 1974 pasal 1.

Usman, Husaini. Metodologi Penelitian Sosial. Jakarta : Bumi Aksara, 2003.

Van Fleet, James K. Manajemen Kepemimpinan, Penerjemah: Ahmad Susanto. Jakarta:Mitra Usaha, 2006.
Yacoob, Abdul Monir dan Shamsiah, Siti. Hukum Keluarga Islam. Jakarta: Kencana, 2006.

Yatim-Irwanto, Danny I. Kepribadian Keluarga Narkotika. Jakarta: Arcan, 1991.

Zahara, Idris dan Lisma Jamal. Pengantar Pendidikan. Jakarta: Gramedia, Widiasarana, 2002. 